\section{$\underset{\substack{\text { hommes } \\ \text { \& migrations }}}{ }$}

\section{Hommes \& migrations}

Revue française de référence sur les dynamiques

migratoires

$1289 \mid 2011$

Les frontières du sport

\title{
Mathias Enard, Parle-leur de batailles, de rois et d'éléphants
}

Actes Sud, 2010, 154 pages, 17 euros

\section{Mustapha Harzoune}

\section{(2) OpenEdition}

Journals

Édition électronique

URL : http://journals.openedition.org/hommesmigrations/825

DOI : 10.4000/hommesmigrations.825

ISSN : 2262-3353

Éditeur

Musée national de l'histoire de l'immigration

Édition imprimée

Date de publication : 1 janvier 2011

Pagination : 151

ISSN : $1142-852 X$

Référence électronique

Mustapha Harzoune, "Mathias Enard, Parle-leur de batailles, de rois et d'éléphants », Hommes \& migrations [En ligne], 1289 | 2011, mis en ligne le 29 mai 2013, consulté le 22 septembre 2020. URL: http://journals.openedition.org/hommesmigrations/825; DOI : https://doi.org/10.4000/ hommesmigrations. 825

Ce document a été généré automatiquement le 22 septembre 2020.

Tous droits réservés 


\title{
Mathias Enard, Parle-leur de batailles, de rois et d'éléphants
}

Actes Sud, 2010, 154 pages, 17 euros

\author{
Mustapha Harzoune
}

\section{RÉFÉRENCE}

Mathias Enard, Parle-leur de batailles, de rois et d'éléphants, Actes Sud, 2010, 154 pages, 17 euros

1 Parle-leur de batailles, de rois et d'éléphants, prix Goncourt des lycéens 2010, évoque le séjour de Michel-Ange à Constantinople où, en 1506, le sultan Bayazid aurait invité le maestro pour construire un pont entre Constantinople et le Péra, au-dessus de la Corne d'Or.

Dans une langue poétique et dense, Mathias Énard donne un roman subtil sur l'altérité - culturelle, religieuse ou sexuelle -, roman sur les ressorts de la création et sur le génie de Michel-Ange qui, à la différence de Léonard de Vinci, un temps pressenti pour la construction de ce pont, aurait compris, lui, “que l'ouvrage qu'on lui demande n'est pas une passerelle vertigineuse mais le ciment d'une cité, de la cité des empereurs et des sultans. Un pont militaire, un pont commercial, un pont religieux. Un pont politique. Un morceau d'urbanité".

Le maître de la Renaissance est ici mis à nu. Et voilà notre artiste dépeint comme un orgueilleux, un vaniteux, colérique et bourru, "malodorant", sûr de son génie mais qui a "sa propre face en horreur". Un impuissant aussi qui s'endort assis, "parce qu'il a peur de l'image de la mort que confere la position allongée". Et tout maestro qu'il est, l'homme n'est qu'un pion dans un jeu qui le dépasse et dont il n'a même pas idée. Michel-Ange s'est esbigné de Rome ; il a délaissé la croix pour servir le croissant, il a pris le risque d'être dénoncé au pape par ses rivaux, jaloux, le grand Raphaël et l'architecte Bramante. Amer et toujours désargenté, il ne peut que constater que "sous tous les cieux il faut donc s'humilier devant les puissants". "Le poète démuni, ivrogne et sans protecteur" Mesihi de Pristina, par ailleurs secrétaire du grand vizir, sera son cicérone et chaperon. Michel- 
Ange finira par être "surpris de s'entendre aussi bien avec un infidèle". Car Parle-leur de batailles, de rois et d'éléphants est aussi un roman de l'entre-deux. Et Constantinople, la “ très douce prison", "balance entre l'Est et l'Ouest comme lui entre Bayazid et le pape, entre la tendresse de Mesihi et le souvenir brûlant d'une chanteuse éblouissante".

4 L'envoûtante androgyne musulmane murmure à l'oreille du chrétien inhibé : "Je ne te connais pas étranger. [...] Prends un peu de ma beauté, du parfum de ma peau. On te l'offre. Ce ne sera ni une trahison, ni un serment; ni une défaite, ni une victoire. Juste deux mains s'emprisonnant, comme des lèvres se pressent sans s'unir jamais." Ces avances resteront vaines : "Tu es capable de tendre une passerelle de pierre, mais tu ne sais pas te laisser aller aux bras qui t'attendent." Mathias Énard semble ici inviter à une introspection de nos consciences et à mesurer ce que l'écrivain américain Toi Derricotte, Noire à la peau blanche, appelait "la persistance des conflits intérieurs, du désir, de la honte et de la terreur".

\section{NOTES}

1. Noire, la couleur de ma peau blanche. Un voyage intérieur, traduit de l'américain par Philippe Moreau, Paris, Éditions du Félin, 2000. 